\title{
As ALTERAÇõES POLÍTICAS DA IGREJA CATÓLICA ENTRE 1967 e 1971
}

\author{
Political Changes in the Catholic Church Between 1967 and 1971
}

\author{
PAUlo Vitor De SOUZA PINTO
}

Universidade De São Paulo, Brasil

\section{KEY WORDS}

History

Catholic Church

Church History
ABSTRACT

This article is the result of a master's research developed in the Graduate Program in Education, at the University of São Paulo. We aim to discuss the political changes of the Catholic Church between 1967-1971. We use the Fraternity Campaigns as a documentary source. At first we identified the Church as a social institution, then we developed the Church's division into conservative, progressive and liberating wings. Finally, it was possible to identify that the Catholic Church presented itself in 1967 as an institution with aspects of the conservative wing. However, over the years, the Church has adopted a more progressive stance.

RESUMO

o presente artigo é resultado da pesquisa de mestrado desenvolvida no Programa de Pós-Graduação em Educação, da Universidade de São Paulo. Temos como objetivo disertar sobre as alterações políticas da Igreja Católica entre 1967-1971. Utilizamos como fonte documental os Campanhas da Fraternidade. Em um primeiro momento identificamos a Igreja como uma instituição social, em seguida desenvolvemos a divisão da Igreja em alas conservadora, progressista e libertadora. Por fim, foi possível identificar que a Igreja Católica apresentou-se em 1967 uma instituição com aspectos da ala conservadora. Entretanto com o passar dos anos, Igreja adotou uma postura mais progressista

Recebido: $18 / 08 / 2020$

Aceite: $30 / 10 / 2020$

\section{GLOBAL我 KNOWLEDGE}




\section{Introdução}

É necessário, antes de mais nada, esclarecer que em nossa pesquisa, abordamos a Igreja enquanto instituição social ${ }^{1}$, utilizando da percepção de "Igreja" feita por Chabalgoity $(2015$, p. 230) "As Igrejas não existem como instituições divinas na Terra, situadas em um vazio. Não são entidades abstratas, mas feitas por homens e mulheres no curso da história". Sobre essa percepção de Igreja que nos propomos a utilizar em nossa pesquisa, Wanderley (1984) afirma:

Desde logo é preciso esclarecer que o termo Igreja significa realidades distintas. Encarandoa aqui como realidade sociológica, ela aparece como uma instituição social que exerce certas funções na sociedade, funções variadas que lhe advêm de sua fé e de suas concepções teológicas. Apesar de seu campo específico se situar na instância teológica, ela pervade os demais planos da realidade social. Há uma dialética entre estes planos, carregada de complexidade e de contradições (Wanderley, 1984, p. 65).

Deste modo, trabalharemos a Igreja, segundo as percepções de Chabalgoity (2015) e de Wanderley (1984). Ao percebermos que a Igreja é complexa e composta por inúmeras contradições ao longo de sua história ${ }^{2}$, entendemos que é necessário realizar um panorama da instituição no período em que o nosso objeto está inserido (1967-1971). Para isso nos apoiaremos na análise realizada por Mitidiero (2008) onde ele identifica que as transformações em curso no Brasil e no mundo ${ }^{3}$, dentro de um contexto social, político e econômico, induzem que a Igreja, enquanto instituição se posicione frente a essas transformações ${ }^{4}$. Mitidiero (2008) evidencia

\footnotetext{
1 “Entendemos por 'Igreja', em sentido estritamente sociológico por oposição tanto à 'seita' como a 'movimento religioso'" (Maduro, Otto, 1981, p. 171 apud Wanderley, 1984, p. 65).

2 “Falar em Igreja, enquanto instituição, isso é, enquanto integrada num determinado povo e região, é referir-se a um processo histórico e aceitar que a Igreja, vista assim, possa evoluir tal como as outras instituições humanas, passando a enfrentar problemas que anteriormente não focalizava" (Alves, 1968, p. 37-38).

3 "O conflito com o poder político, sobretudo a partir dos anos de 1950, com auge durante a ditadura, em 1964-1985, teria provocado uma progressiva desintegração institucional da Igreja, que, desde então, tem procurado ampliar a sua influência no país" (Azevedo, 2004, p. 109).

4 "Por um lado, as dúvidas que a Igreja universal formulou sobre o seu próprio papel a partir da morte de Pio XII e ao longo do Concílio
}

ainda que tal posicionamento por parte da Igreja, forma três "segmentos", sendo eles a "Igreja Conservadora", "Igreja Progressista" e "Igreja Libertadora".

No segmento conservador a Igreja está vinculada aos poderosos e às classes dominantes, se utilizam de determinismos, semelhantes aos utilizados na idade média para controlar a sociedade 5 . Esse segmento imprime características alienantes aos sujeitos, criminaliza comportamentos e culturas que comprometem a estrutura eclesiástica como o divórcio, controle de natalidade, pornografia, o protestantismo, os ritos afro-brasileiros e ideias socialistas (Alves, 1979). Sobre as atitudes da Igreja no Brasil, de uma maneira geral, Alves (1979) ainda afirma que:

A Igreja prosseguiu [...] concentrando a sua atenção sobre as classes dominantes e protegendo-se do que considerava ameaças [...] as regiões pobres foram abandonadas em proveito das mais prósperas, [...] Os setores populares foram abandonados do ponto de vista religioso e promocional. A presença da Igreja entre eles passou a ser quase que apenas uma obra de filantropia. A vasta rede da assistência social que organizou exerceu e exerce funções que lhe são delegadas pela elite governamental. A atividade de assistência social, ligada ao formalismo das manifestações religiosas, criou entre os bispos uma ilusão de poder. Atolaram-se na rotina e na tibieza. Esta ilusão só viria a ser quebrada com a brusca mudança da direção política dos anos sessenta (Alves, 1979, p. 39-40).

Nesse sentido, é possível entender como parcialmente correta ao nos referimos ao segmento conservador da Igreja Católica a afirmação apresentada por Gotat (1981, p. 141) "Marx e os operários da época como também intelectuais entendiam a religião como uma

\footnotetext{
Vaticano II obrigariam a Hierarquia brasileira a perceber-se dos problemas sociais e econômicos do país e a abrir-se às novas correntes teológicas. Por outro lado, a crescente consciência política das massas oprimidas e a resposta ditatorial que provocou por parte das classes dominantes colocaria a Igreja face a uma opção que já não podia ser passiva" (M. M. Alves, 1979, p. 40).

5 Sobre isso (Gotat, 1981, p. 141) cita a encíclica fin dalla prima nostra que diz: "A sociedade humana, tal como Deus a estabeleceu, é composta por elementos desiguais. Consequentemente, está de acordo com a ordem estabelecida por Deus a existência na sociedade humana de príncipes, ricos e pobres, sábios e ignorantes, nobres e plebeus".
} 
expressão da ordem socioeconômica vigente, como uma instituição legitimadora da ordem da opressão". Nesse contexto, o mais correto seria fazer referência direta ao segmento conservador da instituição Igreja, já que o termo religião é generalista, trazendo riscos de uma análise equivocada e reducionista. Esse mesmo segmento chega a apoiar a ditadura militar. Ao aproximar-se das classes dominantes, esse segmento por sua vez atua em caráter assistencialista ${ }^{6}$.

A Igreja Conservadora, avessa a qualquer tipo de transformação social e porta-voz da passividade, apoiava as ditaduras militares e a condução pelas elites do capitalismo selvagem que se estabelecera no continente. Essa Igreja tinha como lema "a ordem, o progresso e a fé", não importando as condições sociais em que grande parte das sociedades se situava. Organizaram a "Marcha da Família com Deus pela Liberdade" e revigoraram um segmento ultraconservador dos católicos chamado "Tradição, Família e Propriedade" (TFP). No Brasil, os principais representantes dessa ala foram os bispos Dom Sigaud de Diamantina, Dom Castro Mayer de Campos e o cardeal Barros Câmara do Rio de Janeiro (Mitidiero, 2008, p. 81).

Considerando que a Conferência Nacional dos Bispos do Brasil (CNBB) é a autoridade máxima da Igreja Católica no Brasil, seus posicionamentos merecem atenção especial em uma avaliação que tem como elementos essenciais a Igreja e sua visão política. Entretanto chamamos a atenção para o fato de a CNBB não ser a única expressão do catolicismo no Brasil7.

\footnotetext{
6 "No assistencialismo a pessoa se comove diante do quadro de miséria coletiva: procura ajudar os carentes. Em função disto organiza obras assistenciais, como pão dos pobres, campanha do cobertor, chá beneficente, Natal da periferia, fornecimento gratuito de remédios etc. tal estratégia ajuda os indivíduos, mas faz do pobre objeto de caridade, nunca sujeito da sua própria libertação. 0 pobre é considerado como aquele que não tem. Não se percebe que o pobre é um oprimido e feito pobre por outros: não se valoriza aquilo que ele tem, como força de resistência, capacidade de consciência de seus direitos, de organização e de transformação de sua situação. Ademais, o assistencialismo gera sempre dependência dos pobres, atrelados às ajudas e decisões dos outros, não podendo ser sujeitos de sua própria libertação" (Boff \& Boff, 2001, p. 16-17).

7 “como em qualquer outra instituição, uma Igreja é influenciada pelas mudanças da sociedade em geral. Mais especificamente, argumento que ideologias políticas da sociedade brasileira tenham influenciado a concepção de fé da igreja. Por sua vez, conflitos sociais, e a forma pela qual o Estado tentou resolvê-los ou suprimi-
}

Durante 1964 e 1968 a CNBB estava focada na política interna da instituição e menos preocupada com questões de caráter social, podemos entender essa afirmação quando olhamos para os documentos da Assembleia Geral da CNBB de 1967, onde ela "apresenta uma concepção de fé que era conservadora em comparação a teologia que havia surgido em alguns círculos latino-americanos [...] nem a reforma social nem a necessidade de uma mudança política faziam parte de sua concepção de fé." (Mainwaring, 1989, p. 105). Ao mesmo tempo, existiram bispos que confrontavam as concepções de fé estruturadas pela CNBB, como é o caso de Dom Helder Câmara, que por questionar as diretrizes da CNBB e ter uma postura conflitiva foi transferido do Rio de Janeiro para o nordeste.

O Brasil carregava no seu episcopado a experiência sofrida de um nutrido grupo de bispos nordestinos, cujo pão cotidiano era a seca, a fome, o drama dos retirantes, dos lavradores sem terra, da injustiça secular. Esta experiência era acompanhada por todo um esforço de passar do mero assistencialismo para soluções mais corajosas e estruturais. Estes bispos estavam na raiz da fundação da SUDENE, [...] encontravam-se a frente do Movimento de Educação de Base, destinado a atingir pelo rádio as populações do interior, levando a educação libertadora (Beozzo, 1985, p. 9)

Sendo assim, é possível perceber que o segmento conservador da Igreja está estruturado a partir de uma lógica excludente e elitista, onde a igreja está distante da realidade social dos povos oprimidos. ${ }^{8}$

Azevedo (2004, p. 112) aponta que as estruturas organizacionais da Igreja, passaram por aquilo que ele chama de "mudança de

los, determinaram em grande escala essas ideologias e concepções da política. A luta política pode fazer com que as identidades sociais $\mathrm{e}$ as ideologias sejam repensadas, criando novas identidades e ideologias. De modo geral, as práticas sociais e as identidades institucionais não se modificam porque surgem novas ideias, mas sim, porque o conflito social leva a uma nova maneira de se compreender a realidade" (Mainwaring, 1989, p. 25)

8 "O Vaticano II [...] é considerado pela ala conservadora como responsável pela decadência da Igreja Católica, e até mesmo julgado apostasia em relação ao Concílio de Trento e ao Vaticano I; tanto assim que houve quem chegasse ao ponto de pedir sua anulação ou uma revisão que equivaleria a tanto" (Ratzinger, Cardinali, apud Beozzo, 1985, p. 52) 
paradigmas" a partir de 1960, especialmente a partir do Concílio Vaticano II $^{9}$ onde a Igreja começa a se abrir para novas filosofias teológicas ${ }^{10}$. É a partir dessa abertura que emana o segmento identificado por Mitidiero (2008) como "Igreja Progressista"

A Igreja Progressista, que criticava abertamente os resultados perversos do capitalismo e as posições e privilégios da Igreja Conservadora, também criticava a ideia de revolução proletária e de sociedade comunista. Ao mesmo tempo em que condenava os efeitos perversos do modo de produção dominante, defendia a "Aliança para o Progresso" e a proposição do "Estado do Bem Estar Social" (Welfare State), acatando a ideologia do país capitalista mais poderoso do mundo: os Estados Unidos. Talvez o emblemático bispo de Olinda Dom Hélder Câmara tenha sido o maior representante dessa corrente. Ele mesclava, contraditoriamente, denúncias às injustiças sociais causadas pelo desenvolvimento do capitalismo com proposição de teses desenvolvimentistas. Dizia ele: "tenho meu modo de lutar contra o comunismo: lutando contra o subdesenvolvimento"; por outro lado, denunciava: "um perigo maior que o comunismo ameaça o mundo, o responsável é o regime capitalista" (Dussel, 1981, p. 66, apud Mitidiero, 2008, p. 81- 82).

Contudo, Azzi (2008, p. 352) nos fornece indícios de que já nos anos 50, alguns clérigos despontavam a abertura da Igreja em relação às questões sociais, ainda que o comunismo fosse uma ameaça para a instituição. Gotay (1981, p. 142) cita a encíclica Divini Redemptoris para elucidar a percepção oficial da Igreja em relação ao comunismo, "O comunismo é intrinsecamente mau, e não se pode admitir que colaborem com ele em terreno algum os que querem salvar da

\footnotetext{
${ }^{9}$ Caliman (2004, p. 231) aponta para três deslocamentos da Igreja Católica que se desdobraram a partir do Concílio Vaticano II, sendo o primeiro, o deslocamento de uma Igreja voltada sobre si para uma Igreja aberta ao mundo de hoje; o segundo deslocamento se refere à transposição de uma Igreja centrada na hierarquia para uma Igreja povo de Deus e o terceiro deslocamento se refere ao passar de uma compreensão universalista para uma a partir da Igreja local ou particular.

10 "Ao mesmo tempo, os conflitos sociais propagaram-se em dimensões mundiais. A violenta inquietação que se apoderou das classes pobres, nos países em via de industrialização, atinge agora aqueles cuja economia é quase exclusivamente agrária: também os camponeses tomam consciência da sua imerecida miséria. Junta-se a isto o escândalo de desproporções revoltantes, não só na posse dos bens, mas ainda no exercício do poder" (Paulo VI, 1967, p. 113).
}

ruína a civilização cristã". Nesse sentido, podemos afirmar que a inserção do "seguimento progressista" junto aos sujeitos "feitos pobres" 11 necessariamente não significa que estes sejam protagonistas da sua história 12 , mas apenas sujeitos de um assistencialismo velado. "A Igreja Católica procurou contrapor-se a esses movimentos de esquerda, oferecendo uma melhor assistência social aos camponeses e atuando progressivamente na esfera de fundação dos sindicatos católicos" (Azzi, 2008, p. 363). É necessário afirmar que a abertura por parte da Igreja, não ocorreu de forma homogênea, Alves (1979, p. 38) aponta que uma parcela pequena de clérigos de fato se importavam com a perda de influência da Igreja junto aos pobres e marginalizados, desta forma é possível perceber que os segmentos conservador e progressista coexistiram em linhas opostas. "As opções feitas pela Igreja durante as últimas décadas fortaleceram sua aliança com as classes populares, mas também a levaram a um distanciamento perante as classes dominantes e o Estado" (Mainwaring, 1989, p. 19).

O terceiro e último segmento identificado por Mitidiero (2008) a "Igreja Libertadora", também descrita por Löwy (1991, p. 33) como "cristianismo da libertação", é fruto das mudanças ocorridas no cenário da Igreja na América Latina e do mundo, a partir da década de 50 .

A Igreja Libertadora representa uma crítica radical à atuação e à hierarquia da Igreja Católica e também à chamada "Teologia do Desenvolvimento" dos teólogos progressistas e, principalmente, ao modo capitalista de produção visto como pecado, como uma afronta à obra de Deus. Esse segmento elaborou uma teologia própria - a Teologia da Libertação - fazendo aproximações entre religião e ciência, entre marxismo e política (socialismo), o que os levou a produzir um discurso político-religioso com o objetivo de intervir na realidade. Os principais representantes dessa parte da Igreja foram os teólogos Gustavo Gutiérrez, Leonardo Boff, Hugo Assmann, Jon Sobrino, Joseph Comblim, entre outros (Mitidiero, 2008, p. 82).

\footnotetext{
11 Termo utilizado por Boff (1990) para descrever a realidade dos sujeitos pobres e marginalizados.

12 "Para o marxismo, a história é tudo. 0 homem não tem essência, tem história" (Gotay, 1981, p. 142).
} 
Löwy (1991) citado por Mitidiero (2008, p. 105) afirma que "a teologia da libertação é um pensamento religioso que utiliza conceitos marxistas e inspira lutas de libertação social como o marxismo faz", (Boff \& Boff, 2001, p. 5051) por sua vez afirmam que a Teologia da Libertação, não se faz obrigada a prestar contas do uso correto ou não das ideias marxistas, utilizando apenas algumas "indicações metodológicas" enquanto uma ferramenta sociológica ${ }^{13}$.

No final dos anos 1960 e inícios de 1970, expressivos setores da Igreja no Brasil e na América Latina como um todo deram uma guinada radical para a esquerda. Foi o surgimento daquilo que Eric Hobsbawm definiu como os padres-católicos-marxistas. Religiosos que se utilizando do instrumental analítico oferecido pelo marxismo desejaram associar à sua práxis cristã a luta por sociedades mais justas ou com menos desigualdades (Silva, 2006, p. 16).

Sendo assim, a partir da análise de Mitidiero (2008) percebe-se que a Igreja Católica da América latina no período em que estamos trabalhando, se posicionou de maneiras diferentes e até ambíguas frente às realidades vivenciadas pelas sociedades daquela época. Cabe ressaltar que se tratando de uma pesquisa de natureza histórica e como elucidamos anteriormente, a nossa pretensão é trabalhar a Igreja enquanto Instituição sociológica. Nesse sentido não nos sentimos obrigados a observar os preceitos e os dogmas da instituição que as define enquanto "una".

\section{Desenvolvimento}

A tentativa de fornecer um panorama da Igreja Católica, durante o regime militar é uma tarefa complexa e de difícil execução, pela sua magnitude geográfica e pluralidade cultural, e sobretudo, pelo fato de que como "qualquer outra instituição, uma Igreja é influenciada pelas

\footnotetext{
13 "O fato de existir uma teologia que tem como um dos seus fundamentos o materialismo histórico dialético, demonstra, por outro ângulo, as franquezas que a concepção marxista clássica tem sobre a religião. Ou seja, o marxismo raso, limitado e vulgar sempre se apresentou de forma dogmática reduzida ao exacerbado materialismo e ao anticlericalismo. Tudo que representava fé ou Deus era considerado essencialmente mal e alienante" (Mitidiero, 2008, p. 106).
}

mudanças na sociedade em geral" (Mainwaring, 1989, p. 25). Após termos esclarecido a divisão em alas da Igreja Católica a partir das terminologias utilizadas por Mitidiero (2008) que ilustram a pluralidade cultural, política e ideológica da instituição, categorizando em três alas distintas, cada uma com sua especificidade, fomentamos a nossa análise com as contribuições de Tomas Bruneau (1974), na tentativa de identificar qual ala da Igreja Católica estava sobressaindo, ou melhor, em destaque naquele período ${ }^{14}$. Contudo essa tentativa se mostrou inconclusiva, pois as divergências entre o posicionamento ${ }^{15}$ oficial da CNBB e o posicionamento de alguns bispos poderiam inviabilizar nossa pesquisa. Sendo assim esclarecemos que vamos reduzir o nosso escopo a analisar apenas a CNBB enquanto representante máxima da Igreja no Brasil, eximindo-nos de analisar o posicionamento dos bispos ${ }^{16}$.

Traremos como fonte documental para nossa análise, os materiais produzidos pela Conferência Nacional dos Bispos do Brasil (CNBB) ${ }^{17}$ para as Campanhas da Fraternidade (CF) de 1967 - 1971. Considerando que as Campanhas da Fraternidade (CFs) realizadas desde 1963 até os dias atuais são propostas para se trabalhar fatos sociais como ponto de partida para sua ação pastoral, entendemos que a $\mathrm{CNBB}^{18}$ pela $\mathrm{CF}$ joga luz sobre temas que são

\footnotetext{
${ }^{14} \mathrm{Em}$ nossa pesquisa entendemos que é necessário compreender o processo de auto identificação que a instituição expressa através de seu discurso e de suas práticas, a partir das mudanças sociais que possam alterar a sua identidade, como afirma Mainwaring (1989, p. 26)

15 “As concepções de fé da própria missão da Igreja não se modificaram somente como resultado de debates acerca de quais deveriam ser ou de como deveriam proteger interesses institucionais. Pelo contrário, sua identidade modificou-se principalmente porque o processo político mais amplo gerou novas concepções da sociedade e do papel da Igreja dentro dela" (Mainwaring, 1989, p. 25).

$16 \mathrm{Em}$ nossa pesquisa entendemos que os posicionamentos de alguns bispos podem ser opostos ao posicionamento oficial da CNBB enquanto representante máxima da igreja católica no Brasil, sendo assim, esclarecemos que apesar de a CNBB representar os interesses da Igreja enquanto instituição, não necessariamente reflete o posicionamento dos bispos.

17 “Foi a CNBB o órgão que [...] organizou o MEB, patrocinou o movimento de sindicalização rural, mantendo um departamento para cuidar do processo de reconhecimento oficial" (Bruneau, 1974, p. 196).

18 “A CNBB foi fundada, em outubro de 1952, por Mons. Helder Câmara e aprovada por Mons. Giovanni Montini, então secretário de Estado do Vaticano. A ideia e os planos para sua organização
} 
pertinentes a toda sociedade, deixando transparecer assim seu posicionamento político ideológico, por isso decidimos utilizar esse material como fonte para nossa análise sobre a conjuntura da Igreja Católica nesse momento.

A Teologia Pastoral tem como objeto material a Igreja e como objeto formal a ação eclesial. [...] a ação da Igreja é a Campanha da Fraternidade, que acontece todos os anos, desde 1963, em âmbito nacional, durante o tempo quaresmal. Ela é a reconhecida como uma importante ação da Igreja no Brasil, não só pelos brasileiros, mas também no mundo todo. Um exemplo desse fato é que diversas universidades do mundo todo solicitam o Texto-base da Campanha da Fraternidade para estudo da realidade brasileira e da ação da Igreja; outro exemplo da sua importância são as cartas enviadas pelo Papa todos os anos por ocasião da sua abertura na Quarta Feira de Cinzas. A Campanha da Fraternidade surgiu a partir de uma situação bem definida e com uma finalidade bem determinada. Porém cresceu, abrangeu muitas outras situações e tornou-se completamente diferente do que era e do que se propunha. A Campanha envolvia as pessoas diante de um desafio que lhes era bem concreto: a penúria daquelas pessoas que eram vistas nas ruas e com quem se podia dialogar diretamente e perceber, sem nenhuma mediação, seus sofrimentos, suas carências, suas dificuldades (Vanzella, 2017, p. 187).

Nesta pesquisa utilizamos os documentos que estão no Setor da Campanha da Fraternidade na Arquidiocese de São Sebastião do Rio de Janeiro, que foram consultados presencialmente, já que estes não possuem versão digital e, portanto, não estavam disponíveis para consulta na internet até o momento em que essa pesquisa estava sendo realizada. Verificamos que o material

nasceram de um diálogo entre os dois, em princípios da década de 1950, e pode-se dizer com segurança que a CNBB estava bem dentro da estrutura e das prioridades de Roma. Logo depois, Mons. Helder Câmara foi nomeado bispo auxiliar do Cardeal Dom Jaime Câmara (nenhuma relação de parentesco), do Rio, e eleito Secretário Geral da CNBB, cargo que ocupou por mais de uma década. Os objetivos de D. Helder ao fundar a organização eram dois: nunca houvera uma coordenação nacional da Igreja, além da que podia ser efetuada por uma personalidade forte como a de Dom Leme, e a necessidade dessa coordenação se tornara urgente com a rápida expansão das dioceses, ocorridas em princípios da década de 50; e achava ele que uma organização nacional como a CNBB animaria a instituição toda a tomar um interesse ativo na mudança social" (Bruneau, 1974. P. 196). analisado está totalmente preservado e organizado cronologicamente, desde a primeira edição da CF até a última em 2019. 0 material está aos cuidados do Pe. Claudio dos Santos que prontamente nos atendeu e proporcionou uma sala para que nossa pesquisa fosse realizada. 0 material está depositado em pastas, organizadas por ano, com seu respectivo conteúdo. Para nossa pesquisa, selecionamos as cinco CFs inscritas no período de 1967 - 1971, os materiais localizados estão identificados na tabela abaixo: 
Tabela 1.

Fontes referentes às Campanhas da Fraternidade (1967- 1971).

\begin{tabular}{|c|c|c|c|}
\hline Ano & Material encontrado & $\begin{array}{c}\text { Estado de } \\
\text { conservação }\end{array}$ & Lema \\
\hline 1967 & Manual da campanha da Fraternidade (1 unidade) & $\begin{array}{l}\text { Totalmente } \\
\text { preservado }\end{array}$ & $\begin{array}{l}\text { Somos todos } \\
\text { irmãos, somos } \\
\text { todos iguais. }\end{array}$ \\
\hline 1968 & Disco de vinil com as músicas da CF (1 unidade) & $\begin{array}{l}\text { Totalmente } \\
\text { preservado }\end{array}$ & Crer com as mãos \\
\hline 1969 & $\begin{array}{l}\text { Disco de vinil com as músicas da CF ( } 2 \text { unidades) } \\
\text { Subsídio litúrgico e síntese do documento base ( } 2 \text { unidades) }\end{array}$ & $\begin{array}{l}\text { Totalmente } \\
\text { preservado }\end{array}$ & $\begin{array}{l}\text { Para o outro o } \\
\text { próximo é você }\end{array}$ \\
\hline 1970 & $\begin{array}{l}\text { Disco de vinil com as músicas da CF ( } 2 \text { unidades) } \\
\text { Síntese do documento base e subsídio de planejamento ( } 1 \text { unidade) }\end{array}$ & $\begin{array}{l}\text { Totalmente } \\
\text { preservado }\end{array}$ & $\begin{array}{l}\text { Ser cristão é } \\
\text { participar }\end{array}$ \\
\hline 1971 & $\begin{array}{l}\text { Disco de vinil com as músicas da CF (1 unidade) } \\
\text { Documento base e subsídios de organização ( } 2 \text { unidades) } \\
\text { Subsídios litúrgicos de pregação ( } 2 \text { unidades) } \\
\text { Separata do Livro "Lendo a Vida" (1 unidade) }\end{array}$ & $\begin{array}{l}\text { Totalmente } \\
\text { preservado }\end{array}$ & Reconciliar \\
\hline
\end{tabular}

Após termos realizado um detalhado estudo dos materiais das Campanhas da Fraternidade estruturamos a nossa análise de maneira cronológica, pois acreditamos que desta maneira será possível ter uma leitura mais clara e concisa, o que para nós é de suma importância já que para entendermos como o Movimento de Educação de Base sobreviveu ao regime militar a partir da hipótese revelada pela bibliografia fundamental, que é "o movimento sobrevive ao regime militar em virtude do seu vínculo com a Igreja", é necessário compreender de que ala da Igreja, e como a Igreja se articulou naquele período.

\subsection{Somos todos irmãos - somos todos iguais}

Durante o ano de 1967, a partir da análise do material da Campanha da Fraternidade deste ano, percebemos um convite por parte da Instituição aos fiéis, para que estes tomem consciência do seu papel de corresponsáveis na atividade evangelizadora. Nesta análise chamamos a atenção para as palavras "participação, ser membro, corresponsável e colaborador" 19 , estas palavras traduzem com

\footnotetext{
19 Durante nossa análise identificamos que outras obras que versam sobre a Igreja nesse período utilizam essa metodologia de
}

clareza a percepção que a Igreja tinha dos fiéis naquele momento. Se durante os anos anteriores a Igreja estava ligada diretamente aos interesses da elite, nesse momento ela começa a pôr em prática uma mudança de postura, aproximandose aos poucos dos interesses da sociedade de uma maneira geral, e percebendo a distância social entre a Igreja enquanto instituição hierárquica e as suas bases. 0 convite feito pela CF de 1967 tem como intenção convocar os leigos para a sua missão participativa dentro da instituição. Contudo, apesar dessa abertura, e do convite feito aos leigos, a Igreja ainda não havia assumido integralmente o espírito do Concílio Vaticano II. Segundo Caliman (2004, p. 224) a Igreja no Brasil durante os primeiros anos pósconciliares buscou evitar os extremos, buscado uma constante interação entre os fiéis e a hierarquia. Chamamos a atenção para o fato que teoricamente houve a proposta de uma abertura por parte da Igreja em relação ao laicato, entretanto a análise do material da CF de 1967 identifica que na prática a Igreja ainda estava vinculada as elites dominantes. Esse fato pode ser comprovado quando vemos que o comitê de

seleção de palavras-chave, citamos a obra de Caliman (2004) in Gonçalves \& Bombonatto (2004), que identifica essas mesmas palavras-chave em uma análise muito próxima a que estamos realizando em nossa pesquisa. 
honra, descrito no documento da CF de 67 era composto por "Juízes, Médicos, Dentistas, Farmacêuticos, Gerentes de jornais e rádios, Negociantes e Gerentes de empresas" em suma indivíduos pertencentes a uma elite e que teriam que decidir pelos grupos paroquiais.

Uma novidade apresentada é o Comitê de Honra, que possa contar com católicos que exercem grande influência sobre a comunidade. Deve ser composta, se for o caso, o juiz, o médico, o farmacêutico, o industrial, representante de associações de classe, sob a presidência do católico mais influente de sua paróquia, aprovado pelo pároco, e obter, inclusive através dele, a participação de outros nomes de prestígio115. É interessante uma análise sobre a criação deste Comitê de Honra, pois é possível verificar que, se por um lado amplia a participação do laicato na realização da Campanha da Fraternidade, por outro é possível perceber um modelo de Igreja que faz acepção de pessoas em vista da conquista dos objetivos propostos. Também podemos perceber que ainda traz resquícios do tempo do padroado porque continua submissa ao poder temporal, não mais ao poder político, mas ao poder social e econômico em vista da satisfação de suas necessidades materiais. 0 Comitê de Honra é um poder figurativo que rende. Na verdade, ele nunca foi implantado nas Dioceses. (Vanzella, 2017, p. 54)

Sendo assim, é possível perceber que a abertura ao laicato, proposta pelo Concílio Vaticano II, começa a forçar a hierarquia da Igreja Católica a ter uma mudança de posicionamento. Essa mudança por sua vez não foi instantânea, mas lenta e gradual. A partir da análise do conteúdo desses materiais, podemos perceber que o material da CF aparenta um tom que pode levar a compressão da inserção de uma ala progressista, tanto na sua escrita, quanto na ilustração do material onde são apresentados uma menina branca com uma boneca e um menino negro com uma bola, abaixo do título "Somos todos iguais somos todos irmãos".
Figura 1: Cartaz da Campanha da Fraternidade de 1967

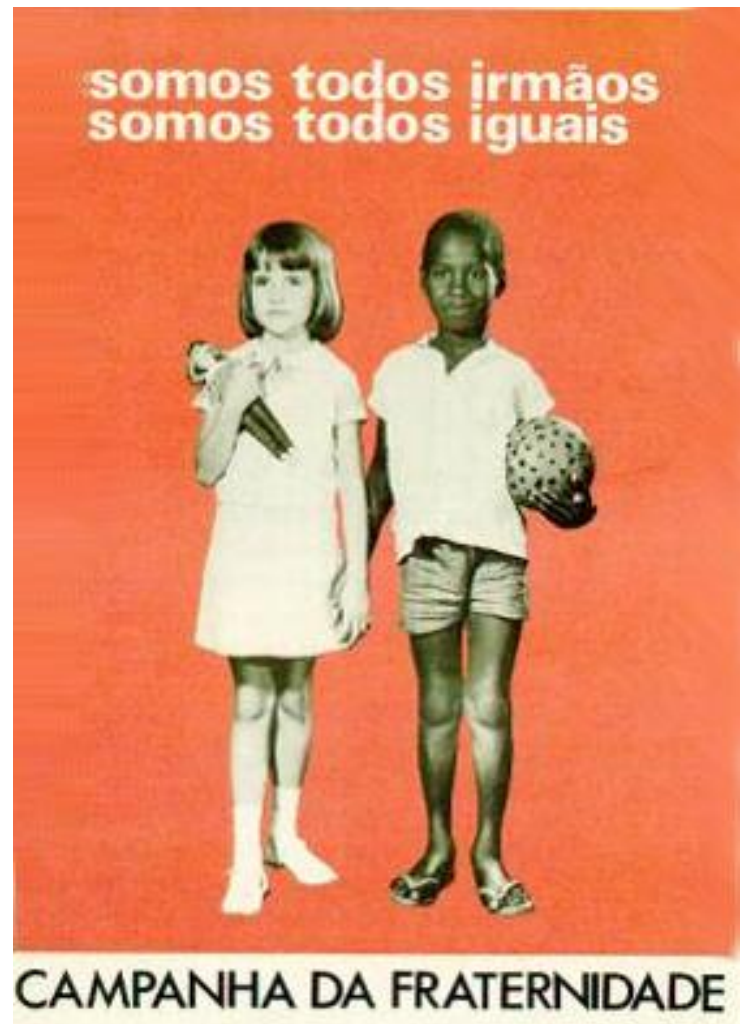

Fonte:

http://medianeirabr.blogspot.com/2013/01/campanhada-fraternidade-cf.html

Contudo uma análise exclusiva desse material da CF seria reducionista e nos induziria ao erro, nesse sentido, esclarecemos que nossa análise foi balizada por outras obras que são amplamente utilizadas ao longo da nossa pesquisa. Deste modo essas obras ${ }^{20}$ nos ajudaram a perceber que a CF de 67 tem um fenótipo da ala progressista, tanto pela constituição do seu texto, quanto pela sua ilustração, entretanto percebemos que essa campanha possuiu em sua composição grupos conservadores e elementos identificados na ala conservadora apresentada por Mitidiero (2008). Bruneau (1974) corrobora com nossa percepção quando afirma que mesmo após a publicação da Populorum Progressio, uma encíclica tida como "extremamente progressista", e em uma situação onde o Brasil enfrentava uma situação de miséria, desemprego e outros fatores que vieram

${ }^{20}$ Aqui faço referência as obras de Bruneau (1974); Caliman (2004); Mainwaring (1989), Documentos de Paulo VI (1997); Beozzo (2004) e Mitidiero (2008). 
com a ditadura militar, a VIII Assembleia Geral da CNBB realizada em Aparecida - SP em maio de 1967 ficou restrita apenas a questões de doutrina e administração interna da instituição.

Dom Helder apresentou uma declaração sobre a "Populorum Progressio e o Brasil", que foi muito pouco discutida e não teve qualquer repercussão pública; além disso, ele não conseguiu acrescentar à agenda um item sobre a redistribuição de terras da Igreja. Muitos observadores, inclusive dentre o clero, compreenderam que a Igreja, como ficava demonstrado nesse encontro, tinha recuado não apenas das preocupações sociais, mas também de qualquer atividade de inovação (Bruneau, 1974, p. 227- 228).

O lema da Campanha da Fraternidade "somos todos Iguais, somos todos irmãos" ilustra ainda um posicionamento de omissão e de distanciamento da instituição em relação aos efeitos da repressão e aos problemas sociais que estavam ocorrendo naquele momento, que foram amplamente trabalhados na populorum Progressio, consequentemente um reflexo de uma instituição que não quer se levantar contra o regime militar. A alteração dos quadros da CNBB antes do golpe de 1964 e pós-golpe trouxe resultados catastróficos, enquanto no período antes do golpe, existia uma busca por lutar contra os problemas sociais, com a instauração do regime militar as estruturas da igreja no Brasil também são alteradas. Bruneau (1974, p. 220) ratifica esse evento quando entende também que a CNBB no período pós-golpe não possui mais as mesmas lideranças progressistas do período pré-golpe, mas sim, uma estrutura burocrática e sem nenhum comprometimento com os compromissos anteriores que a CNBB desenvolveu até então. Três anos depois do golpe, os efeitos dessas mudanças são notavelmente perceptíveis. A igreja no Brasil, não estava preparada para conjugar as ideias do Concílio Vaticano II, que por sua vez, levanta temáticas de caráter social, como fome, desemprego e pobreza, entre outros temas que não eram necessariamente relevantes, tanto para a hierarquia eclesiástica naquele momento, quanto para o regime militar. Desta maneira é possível compreender a relação de crise e regressão que Bruneau (1974) afirma que a instituição sofreu nesse período21. Essa CF tem como objetivo reativar a consciência de que todos são membros do povo de Deus, corresponsáveis por toda comunidade da Igreja local, diocesana, nacional e universal. No manual analisado, selecionamos como palavras chaves: participação, ser membro, corresponsável, colaborador. Entendemos que em 1967 a Igreja está atuando como assistencialista, onde o leigo é visto como "membro" e corresponsável pelas ações da Igreja, ele participa apenas como colaborador.

Percebemos uma Igreja elitista onde os ricos decidem pelos mais pobres, um exemplo disso pode ser verificado no documento da CF de 1967, onde o "comitê de honra" é composto por, pessoas que detém de um poder econômico e social, é perceptível que o pobre é excluído dos espaços decisórios, o que justifica nossa ideia de uma igreja conservadora que caminha sentido à ala progressista. Esse movimento de transição da ala conservadora para a ala progressista ambas ilustradas por Mitidiero (2008), acabam, no nosso entender, por criar uma quarta ala dentro da Igreja Católica, que podemos chamar de "Moderados". Inicialmente houve um grande receio em admitir a existência de uma quarta ala, pois nos afastaríamos do referencial teórico que fundamentou a nossa compreensão sobre a categorização em alas. Contudo tanto algumas obras utilizadas em nossa pesquisa fazem alusão a um grupo, ou ala, identificada como "os moderados", como durante a entrevista com José Renato, ex-integrante da equipe nacional do MEB durante o período que estamos trabalhando em nossa pesquisa, ele nos chama a atenção para participação do grupo identificado como "moderados". Desta forma, esclarecemos que os moderados são aqueles que estão no processo de transição entre uma ala conservadora e uma ala progressista, que iluminados pelo Concílio Vaticano II, pelos desdobramentos da situação socioeconômica e política que o Brasil vivencia22,

21 "O Concílio não encontrou uma base organizacional na Igreja do Brasil, mas sem dúvida nenhuma estimulou nela uma inquietação" (Bruneau, 1974, p. 229).

22 “As rápidas mudanças do período de 1964-1973 resultaram de uma conjunção de alterações na política e na sociedade brasileiras e mudanças na Igreja internacional. Seja como resultado da tortura, das infames desigualdades em São Paulo, da violência contra os camponeses nas áreas fronteiriças do Amazonas ou da repressão da Igreja no Nordeste" (Mainwaring, 1989, p. 131- 132). 
além dos interesses em proteger a própria instituição, assumem a defesa de alguns interesses da ala progressista. Sobre isso Mainwaring (1989, p. 131) afirma que:

A CNBB ainda não acompanhava os grupos episcopais das regiões mais progressistas, mas ela percorrera um longo trajeto. Após ter quase dado apoio ao regime militar (1964 - 1968), levantou uma voz tímida contra os excessos da repressão (1968 - 1972) e finalmente se firmou nas críticas às violações dos direitos humanos (1973 - 1982). (Mainwaring, 1989, p. 131)

Sendo assim, os resultados encontrados por nossa pesquisa, nos dão indícios de que a CNBB em 1967 está iniciando o processo de transição, de uma Igreja conservadora para uma Igreja progressista, esse evento de transição é identificado como a ala moderada. Bruneau (1974, p. 256) realiza uma contribuição significativa para o entendimento do processo de transição que a Igreja estava passando. "Podemos afirmar que a promoção dos leigos está a exigir caminhos novos para a sua efetivação. 0 que se tem feito, e mesmo as perspectivas que se abrem, parecem tímidas em face das exigências do momento e de opções a serem tomadas" (Regionais em Foco, de nacionais informam, de 15 de março de 1968, pág. 16 apud Bruneau, 1974, p. 256). Sendo assim, a nossa pesquisa apresenta a Campanha da Fraternidade de 1967 como uma tentativa tímida da CNBB em assumir as ideias do Vaticano II, com um lema distante dos problemas reais vivenciados durante a ditadura militar, com uma ilustração genérica e reducionista para o contexto brasileiro, reforçando os papeis de gêneros cristalizados - a menina carrega a boneca e o menino carrega a bola -.

\subsection{Para o outro o próximo é você}

O ano de 1969 a nível nacional foi marcado pelo endurecimento do regime militar, e a nível LatinoAmericano, começaram a ser percebidos os desdobramentos da Conferência de Medelín, onde a Igreja voltou o seu olhar para o homem latinoamericano, sob a justificativa que "para conhecer a Deus é necessário conhecer o homem" (CELAM 1968). O documento da II Conferência Episcopal Latino-Americana afirma que:
A Igreja latino-americana julga dever orientarse para a formação de comunidades nacionais, que refletem uma organização global, onde toda a população, porém, especialmente as classes populares, tenha, através de estruturas territoriais e funcionais, uma participação receptiva e ativa, criadora e decisiva, na construção de uma nova sociedade. Essas estruturas intermediárias entre a pessoa e o Estado devem ser organizadas livremente, sem uma intervenção indevida da autoridade ou de grupos dominantes, no seu desenvolvimento e na sua participação concreta na realização do bem comum total. Constituem a trama vital da sociedade. São também a expressão real da liberdade e da solidariedade dos cidadãos (CELAM, 1968, p. 4- 5).

Nesse sentido, a CNBB, observando as conclusões do Conselho Episcopal Latino Americano (CELAM) ${ }^{23}$ (1968) ${ }^{24}$ assume uma postura mais engajada em relação aos anos anteriores ${ }^{25}$, o que é possível verificar, quando

23 "No ano de 1955 foi criado o CELAM. Esse organismo seria encarregado de promover a reflexão teológica, pastoral, em uma palavra, eclesial, da Igreja Latino-Americana tornando-se, com o decorrer dos anos, o instrumento mais eficaz para a autoidentificação desta Igreja. É significativo verificar o crescente interesse que, a partir daquela época, "as coisas" latino-americanas vêm despertando nas velhas cristandades da Europa, as quais começaram a criar toda uma cadeia de instituições de ajuda à carente Igreja latino-americana. Entre elas: a Obra de Cooperação Sacerdotal Hispano-Americana (OCSHA, 1949), iniciativas "Fidei Donum" de muitas dioceses europeias com dioceses da América Latina, a Ação Episcopal Adveniat do Episcopado alemão, pela qual passaram, nestes últimos anos, centenas de projetos pastorais pedindo ajuda financeira, o College pour L'Amérique latine de Lovaina, The Society of St. James do Cardeal Cushing e outros [...] Medellín 1968 foi o primeiro fruto maduro do CELAM. Foi para a América Latina o que o Concílio foi para a Igreja Mundial" (PAPE, et al., 1983, p. 25)

24 "O documento final - A Igreja na atual transformação da América Latina à luz do Concílio -, que se tornou mais conhecido sob a denominação Conclusões de Medellín, dedica toda uma seção ao tema da educação, que é considerado pelo episcopado um fator básico e decisivo no desenvolvimento do continente. Por educação, as Conclusões de Medellín referem-se não só à educação formal, mas a todo processo formativo, até mesmo não-sistemático, abrangendo crianças, jovens e adultos [...] para que a educação possa ser libertadora, ela deve ser, segundo o episcopado de Medellín, criadora em todos seus níveis. Deve ainda capacitar tecnicamente, preparar para o diálogo, aprofundar a consciência da dignidade humana, promover o senso comunitário e levar à afirmação das particularidades locais e nacionais, integrando-as na unidade pluralista do continente" (ANDRADE, 2004, p. 416- 417).

25 "Os bispos e a CNBB romperam a censura imposta à palavra livre no Brasil (a partir de 1968) e anunciaram e denunciaram as violações sistemáticas aos direitos humanos, às torturas, à insuficiência dos salários, à expropriação das terras. A Igreja se o tributo do povo. Criaram-se vários organismos que dão eficácia à luta pela justiça: Comissão de Justiça e Paz ao nível Nacional, 
analisamos a Campanha da Fraternidade de 1969 , e percebemos que algumas palavras-chave novas passam a compor o vocabulário do documento da CF desse ano, tais como: Consciência; responsabilidade; participação e promoção humana. Essas palavras identificadas no manual da CF de 69 foram uma alusão direta aos resultados da Conferência de Medelín que abordam temáticas como consciência e responsabilidade.

Nossa missão pastoral é essencialmente um serviço de inspiração e de educação das consciências dos fiéis, para ajudar-lhes a perceber as exigências e responsabilidades de sua fé, em sua vida pessoal e social. Dentro dessa perspectiva, a Segunda Conferência Episcopal quer evidenciar as mais importantes para os países de nosso continente, tendo em conta o juízo de valor que, sobre a situação econômica e social do mundo de hoje, emitiram os últimos documentos do magistério da Igreja, e que no continente latino-americano tem plena vigência (CELAM, 1968, p. 14)

$\mathrm{Na}$ Campanha da fraternidade de 69 chamamos a atenção, ainda, para o uso maciço dos meios de comunicação, como foi descrito no item III da síntese do Documento Base da CF, que ilustram que a CNBB colocou em prática as conclusões da Conferência de Medelín. ${ }^{26}$ Nesse mesmo item do documento Base a CF é descrita como uma campanha "Educativa da consciência da Igreja”. Uma diferença significativa é que diferente das CFs anteriores o leigo começa a ser integrado em espaços específicos, criados para estimular a participação do laicato na instituição.

Mainwaring (1989, p. 122) esclarece ainda, que posterior ao ano de 1968, a CNBB assume uma postura mais crítica em relação ao capitalismo e ao Estado. Considerando a

diocesano e em muitos lugares em cada paróquia ou comunidade de base. CIMI: Conselho Indigenista Missionário, órgão ligado à CNBB e encarregado de ajudar os índios na defesa de suas terras e de sua cultura. CPT: Comissão de Pastoral da TERRA: órgão que acompanha os problemas das terras, onde as violências assumem formas extremas. Movimento Custo de Vida que mobilizou mais de 1 milhão de pessoas. Observemos: todos estes órgãos não visam defender os interesses corporativos da Igreja, mas do povo esbulhado. É um serviço da Igreja ao oprimido contra o pecado do esbulhamento a que está submetido" (Boff, 1982, p. 43)

26 "Despertar nos homens e nos povos, principalmente através dos meios de comunicação social, uma viva consciência da justiça, inspirando-lhes um sentido dinâmico de responsabilidade e solidariedade" (CELAM, 1968, p. 14- 15). afirmação que Mainwaring (1989) faz no prefácio de seu livro "durante o período de maior repressão (1968-1974), a Igreja, com frequência, era a única instituição com suficiente autonomia política para criticar o regime autoritário e para defender os direitos humanos" (MAINWARING, 1989, p. 9). Entendemos que a ala moderada da CNBB deu mais um passo no sentido progressita, sobretudo depois de 18 de fevereiro de 1969, quando em virtude da repressão contra a Igreja, a CNBB assume a questão dos direitos humanos e realiza críticas ao AI-5.

Os bispos criticaram o AI-5 por permitir violações arbitrárias dos direitos humanos, inclusive sua restrição à auto defesa em tribunal, o direito de expressar opiniões e o direito à informação. Criticaram o governo militar por ameaçar a dignidade física e moral do indivíduo e por estimular uma radicalização maior da situação política (Mainwaring, 1989, p. 130).

O documento-base da CF de 1969 deixa claro sua intenção de "formar uma consciência de Igreja", sendo assim entendemos que o tema da descoberta da alteridade, abordado pela CF sob o lema "Para o outro o próximo é você" vivifica a consciência de que todos são responsáveis por lutar contra as desigualdades e injustiças, frutos do capitalismo selvagem que oprime e segrega as pessoas. Essa Campanha, conta com dois instrumentos que fortalecem a conscientização do processo de opressão, que também podem ser considerados instrumentos de denúncia das estruturas opressoras, são eles o documento de Paulo VI, a Populorum Progressio e o Relatório da reunião de Medelín (1968). Vanzella (2017) contribui com nossa análise sobre a Campanha da Fraternidade de 1969 afirmando que essa campanha aborda a temática do desenvolvimento integral e solidário do serhumano, evocando a necessidade da construção de uma sociedade solidária e fraterna. A iconografia da CF de 69 ilustra o gesto de solidariedade com o estender de uma mão, chamamos a atenção para a palavra "próximo" que está sublinhada no cartaz. Nesse contexto o termo "próximo" comporta dois significados, tanto o que vem depois, (seguinte), quanto o de proximidade. 
Figura 2: Cartaz da Campanha da Fraternidade de 1969

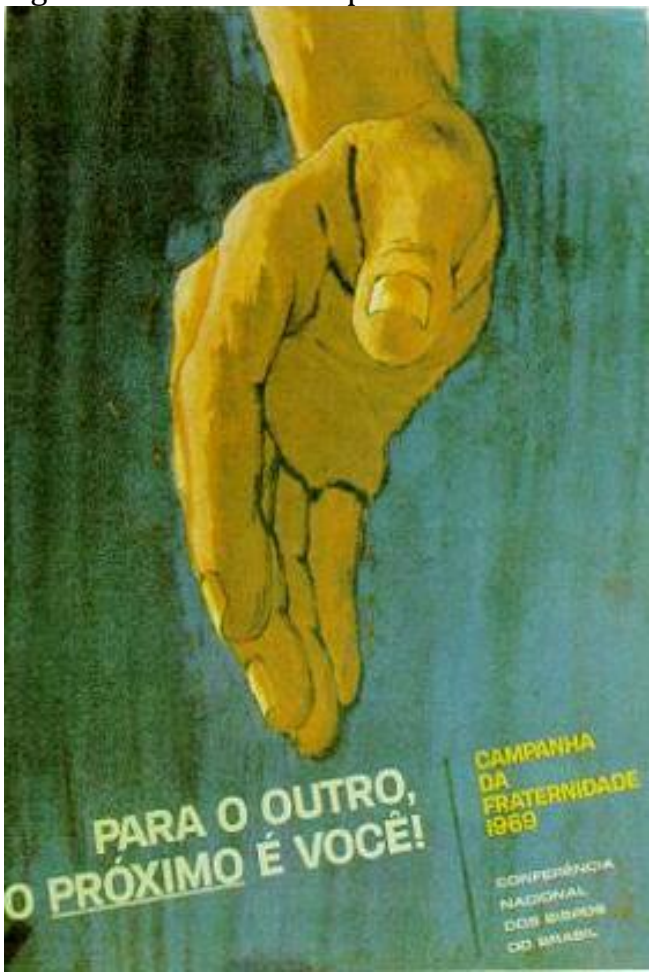

Fonte:

http://medianeirabr.blogspot.com/2013/01/campanhada-fraternidade-cf.html

Por fim, entendemos que depois de Medelín, a CNBB foi gradativamente reformulando o seu papel enquanto instituição, e assumindo uma postura mais combativa contra a realidade social de opressão e repressão, inserindo-se gradativamente na vida e na realidade dos sujeitos "feitos pobres por instrumentos que ofendem a dignidade humana" como afirma Boff (1990).

\subsection{Ser cristão é participar}

A Campanha da Fraternidade de 1970 foi fruto das reflexões dos anos anteriores, com o amadurecimento da CNBB em relação a questões que permeavam a sociedade brasileira e as reflexões realizadas sobre o encontro de Medelín (1968) e da encíclica Populorum Progressio. Nessa CF identificamos maior participação dos leigos nas organizações antes dominadas pela hierarquia clerical, diferente das Campanhas anteriores, na Campanha de 70, o leigo passa a ter um papel de protagonista, não mais de ator coadjuvante, ou mero figurante. 0 próprio documento base da CF em sua apresentação diz:
"Em todos os níveis de trabalho da CF a maioria deve ser de leigos". Nessa CF é possível identificar que a percepção da CNBB em relação ao leigo é mais madura em relação às anteriores, especialmente no que se refere ao contexto sociopolítico, econômico e eclesiológico.

Figura 3: Cartaz da campanha da Fraternidade de 1970

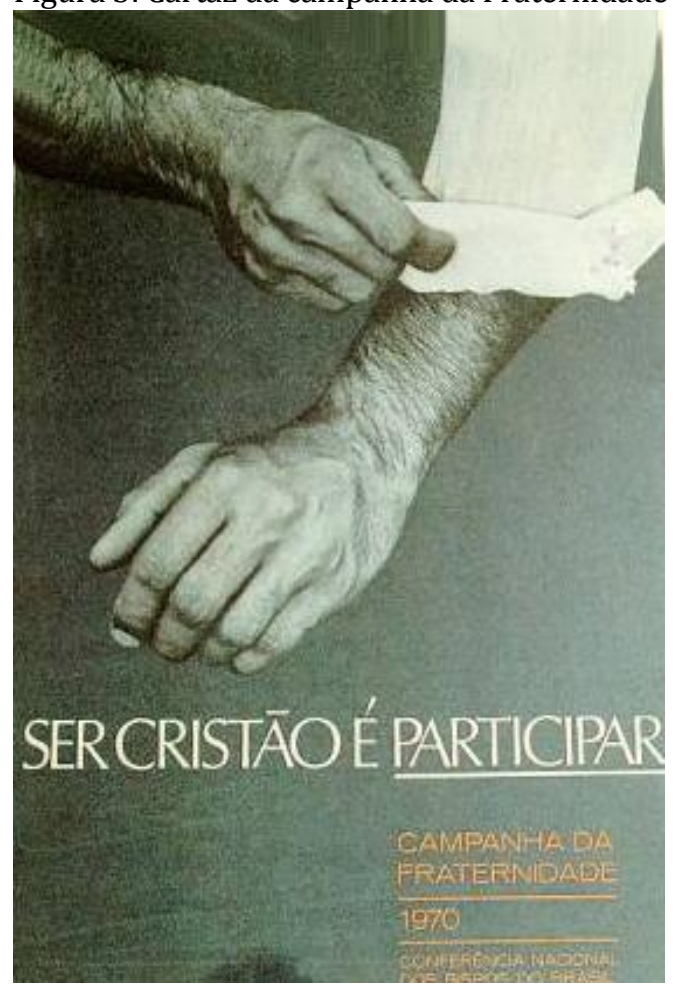

Fonte:

http://medianeirabr.blogspot.com/2013/01/campanhada-fraternidade-cf.html

Em maio de 1970, durante a XI Assembleia Geral, a CNBB assume de fato um posicionamento de conflito direto contra a ditadura militar, denunciando os abusos do regime, problematizando incisivamente a tortura praticada pelo governo. No texto da assembleia a CNBB declara que:

Não podemos admitir as lamentáveis manifestações da violência, traduzidas na forma de assaltos, sequestros, mortes ou quaisquer outras modalidades de terror. (...) Pensamos primeiramente no exercício da JUSTIÇA, (...) que, sinceramente, cremos estar sendo violentado com frequência, por processos levados morosa e precariamente, por detenções efetuadas em bases suspeitas ou acuações precipitadas, por inquéritos 
instaurados e levados adiante por vários meses, em regime de incomunicabilidade das pessoas e em carência, não raro, do fundamental direito de defesa (...) Seríamos omissos se não frisássemos, neste momento, nossa posição firme contra toda e qualquer espécie de tortura. (Documento da XI Assembleia Geral da CNBB, p. 85 -86 apud Mainwaring, 1989, p. 130).

Segundo Mainwaring (1989) em 1970 tanto os moderados quanto os conservadores começaram a combater a violação dos direitos humanos e os abusos cometidos pela ditadura militar, dentre os quais citamos a tortura de membros do comitê e dos padres assessores da JOC (Juventude Operária Católica) na sede nacional, no Rio de Janeiro, a prisão de padres e outros jocistas em São Paulo, Belo Horizonte MG e Volta Redonda - RJ , invasão na PUC - Rio. Desta forma, entendendo o contexto vivenciado durante a ditadura percebemos que o convite da Campanha da Fraternidade foi sobretudo necessário, pois possibilitou que os leigos tivessem um espaço onde pudessem participar definitivamente. A imagem do cartaz reflete o "arregaçar as mangas" e partir para ação. Por fim, percebemos que a CNBB não estava mais com a mentalidade de uma Igreja distante do leigo, mas sim, o leigo definitivamente passa a compor a Igreja. E é dentro do contexto de abertura e participação dos leigos na Igreja, de conscientização de promoção humana, que emanam a Comunidades Eclesiais de Base (CEB's) 27 e onde identificamos os primeiros sinais da igreja libertadora, comprometida com a mudança social a partir do processo de tomada de consciência da realidade injusta.

\footnotetext{
27 "Durante os anos de 1964-1971, dinamizaram-se as bases, pois começavam a desenvolver-se todas as características fundamentais da Igreja popular. Entre as inovações mais importantes estava o surgimento das comunidades eclesiais de base (CEBs). Uma CEB é um grupo pequeno [...] que geralmente se reúne uma vez por semana, usualmente para discutir a bíblia e sua relevância face as questões contemporâneas. Seus membros são responsáveis pelas cerimonias religiosas do grupo, assim como por muitas decisões [...] as Comunidades Eclesiais de Base tornaram-se uma das contribuições de maior destaque da Igreja brasileira ao catolicismo [...] a partir de suas leituras da Bíblia, muitos participantes das CEBs se envolveram nos movimentos populares [...] muitas CEBs surgiram porque não havia outra forma de fazer um trabalho pastoral mais intenso, senão delegando maior autonomia aos leigos" (Mainwaring, 1989, p. 127-128).
}

Neste modelo, os ministros da Igreja são, antes de tudo, assessores e coordenadores e os leigos são sujeitos que devem agir em conjunto com os demais leigos e os ministros ordenados, buscando a unidade com Cristo e a ação conjunta na história [...] O surgimento das Comunidades Eclesiais de Base - CEBs, integradas principalmente nos setores suburbanos e camponeses, de maioria pobre e simples, procurando viver em comunidade e unir a fé com a vida e assumindo o compromisso social pela mudança (Vanzella, 2017, p. 136-137).

Por sua vez, apesar do discurso da CNBB apresentar alguns aspectos da ala libertadora, não foram encontrados elementos contundentes que pudessem comprovar que a CNBB durante esse período teve alguma ligação direta com a ala libertadora, segundo as definições de Mitidiero (2008). Sendo assim, entendemos que a CNBB nesse momento possui características mais próximas à ala progressista.

\subsection{Reconciliar}

A Campanha da Fraternidade de 1971, a última que vamos abordar em nossa análise, é a única no período que nossa pesquisa está abordando, que adentra na questão da educação, especificamente um movimento de conjugação de forças para a educação de adultos, proposta já levantada em Medellín em 196828. No cartaz da Campanha, vemos o aperto de mãos, que simboliza o acordo entre duas partes, já que no contexto da reconciliação temos uma parte que pede desculpas e outra que aceita as desculpas. Em segundo lugar, temos quatro mãos que simbolizariam os pontos cardeais norte, sul, leste e oeste. E por fim uma ilustração do planeta Terra, que conjugados ilustram os quatro cantos da terra unidos em um único objetivo, o de reconciliar.

\footnotetext{
28 “A Igreja toma consciência da suma importância da educação de base. Em atenção ao grande número de analfabetos e marginalizados na América Latina, a Igreja, sem poupar sacrifício algum, se comprometerá a promover a educação de base, que não visa somente alfabetizar, mas também capacitar o homem para convertê-1o em agente consciente de seu desenvolvimento integral" (CELAM, 1968 apud Andrade 2004, p. 417).
} 
Figura 4: Cartaz da Campanha da Fraternidade de 1971

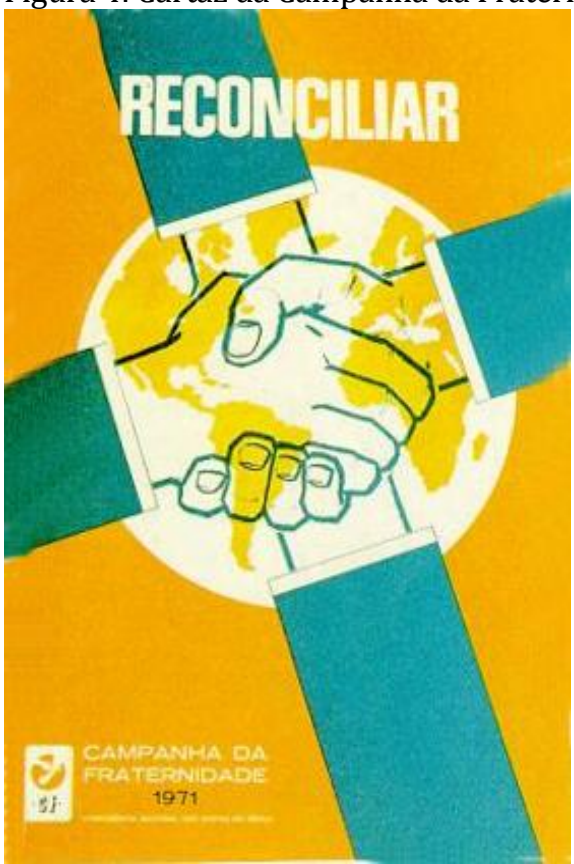

Fonte:

http://medianeirabr.blogspot.com/2013/01/campanhada-fraternidade-cf.html

A reconciliação abordada na CF está diretamente ligada à promoção humana, que é uma proposta que a Igreja vem trabalhando desde 1968. Sobre a relação entre a reconciliação e a educação a CNBB afirma que:

A mensagem de reconciliação assume $o$ entendimento de que o perdão ao outro é mais urgente que a oferta no altar. Durante esse tempo, cantou-se: "Não basta sete vezes perdoar/ mas, setenta vezes sete, sem contar". (Mt 18,21). Ensina-se que a capacidade de perdoar não tem limites e que o perdão é uma atitude política que pressupõe conversão e transformação. Este é um difícil momento político. Na pauta das discussões está a Lei de Reforma da Educação Brasileira que objetiva formar cidadãos dóceis ao regime político vigente. As forças de resistência parecem quase vencidas. Em resposta, a Igreja lança mão de uma outra estratégia de evangelização: reforçar valores éticos também no espaço escolar (CNBB, Campanhas s.d.).

Sobre a Campanha da fraternidade com o tema reconciliação e sua relação com a educação o Papa Paulo VI envia uma carta comentando:
Reconciliemo-nos, pois, para promovê-los, com os pobres, com os que choram, com os doentes, com os sem-teto e sem-pão e com os que, abatidos, se encontram «à beira do caminho», à margem da civilização, do progresso e da sociedade. Em particular, reconciliemo-nos com os que não sabem ler nem escrever e não possuem a consciência da própria dignidade de homens e de filhos de Deus. Nada aproveita deter-se a perguntar, de quem é a culpa: se deles mesmos, se das condições adversas em que transcorre a sua vida. Eles são aos milhões, ao nosso lado. Sejamos generosos, pela única maneira eficaz de os ajudar; alfabetizando-os, conscientizando-os, com espírito evangélico (Paulo VI, 1971).

A Campanha da Fraternidade de 1971 busca conscientizar os católicos para reconciliação e convida-os para que realizem um intenso movimento de promoção humana. Nessa CF há ainda uma preocupação com a realidade de opressão da sociedade brasileira e com a educação de base.

Sendo assim, pudemos perceber que com o passar do tempo a Igreja no Brasil, consegui gradativamente realizar o aggiornamento proposto pelo Concílio Vaticano II, a mudança de lugar social, ou seja, de uma Igreja vinculada aos poderosos, para uma Igreja que denuncia os poderosos e se vincula aos sujeitos feitos pobres, Cleto Caliman (2004, p. 243) confirma nossa análise dizendo sobre a Igreja que: "ela deixa o lugar do poder do Estado ou de uma classe social e vai para a sociedade civil. Dentro da sociedade civil ela vai do lugar da classe hegemônica para o mundo dos pobres (CALIMAN, 2004, p. 243).

0 processo pedagógico da missão da Igreja, difundido pelas Campanhas da Fraternidade, parte do processo de conscientização, passa pelo exercício da corresponsabilidade e se concretiza na participação, concluindo assim o processo de tornar-se sujeito dentro da Igreja. 0 maior exemplo da concretização da participação dos sujeitos está nas Comunidades Eclesiais de Base (CEBs) que se expandiram a partir dos anos 70, e que contribuíram significativamente para a educação popular. Wanderley (1984, p. 36) sintetiza os novos compromissos assumidos pela Igreja: 
uma teologia marcada pelo compromisso de fé e transformação do mundo; críticas oficiais ao sistema capitalista e reivindicações de reformas estruturais; fissuras na vinculação ao bloco dominante e inclinação para povo no campo; luta pela maioridade do leigo na Ação Católica particularmente na JUC (Juventude Universitária Católica); luta pela democratização da educação; participação política ativa de grupos cristãos em posições de esquerda e primeiros grupos defendendo possibilidades de opção pelo socialismo (Wanderley, 1984, p. 36).

\section{Conclusão}

Em síntese, tentamos ilustrar a mudança de posicionamento da CNBB, a partir da análise do material das Campanhas da Fraternidade, de 1967 até 1971, balizada pela bibliografia utilizada: A Igreja Católica e política no Brasil 1916-1985 (Mainwaring 1989); Catolicismo brasileiro em época de transição (Bruneau 1974); A eclesiologia do Concílio Vaticano II e a Igreja no Brasil (Caliman, 2004 in Gonçalves \& Bombonatto, 2004); Por uma Igreja ministerial (Almeida, 2004 in Gonçalves \& Bombonatto, 2004); O Vaticano II e a Igreja Latino-Americana (Beozzo 1985), e A ação territorial de uma Igreja radical: Teologia da Libertação, luta pela terra e atuação da Comissão Pastoral da Terra no Estado da Paraíba (Mitidiero 2008); Sendo assim, entendemos que a Campanha de 1967 ilustrava um posicionamento da CNBB que se confundia entre conservador e moderado, quando já em 1968 temos uma Campanha predominantemente moderada, com uma leve inclinação para a ala progressista, em 1969 identificamos o declínio da ala conservadora e moderada, e uma campanha que se aproxima mais da ala progressista. Já em 1970, percebemos o alvorecer de aspectos da ala libertadora, mas uma campanha identificada como progressista, o que também se segue no ano posterior 1971.

Sendo assim, percebemos que os posicionamentos que a CNBB assume ao longo do tempo coexistem entre si, ou seja, a CNBB assume uma postura progressista, mas ainda possui em seu meio, aspectos conservadores. Boff (1982) fortalece nossa percepção apontando que na Igreja existem dois comportamentos que coexistem, um voltado para o mundo e para a sociedade e outro voltado para as estruturas hierárquicas internas, o que pode ser um indício do motivo pelo qual a CNBB não teve uma manifestação plena da Teologia da Libertação. É nesse contexto que acontece a eclesiogênese, ou seja, o surgimento de uma Igreja nova, gestada no coração da velha. Assim como os filhos carregam códigos genéticos dos pais em seu DNA, a eclesiogênese acompanha esse mesmo processo, é uma Igreja nova, que tem em seu interior os resquícios da estrutura hierárquica. Por isso a CNBB não assumiu plenamente a Teologia da Libertação, e é identificada em nossa pesquisa, a partir da bibliografia e das produções das Campanhas da Fraternidade, que ilustram o posicionamento da CNBB em relação a sociedade como uma instituição que se apresenta inicialmente como conservadora e vai sofrendo alterações que caminham em sentido a ala progressista. 


\section{Referências}

Alves, M. M. (1979). A Igreja e a Política no Brasil. São Paulo: Brasiliense.

- (1968). o Cristo do povo. Rio de Jnaeiro: Sabiá.

Andrade, P. F. (2004). A educação do ser humano realizada no diálogo entre fé e cultura, A contribuição do Concílio Vaticano II. In P. S. Gonçalves, \& V. I. Bombonatto, Concílio Vaticano II, Análise e prospectivas (pp. 405- 417). São Paulo : Paulinas.

AzzI, R. (2008). História da Igreja no Brasil: ensaio de interpretação a partir do povo: tomo II/3-2: terceira época: 1930-1964. Petrópolis: Vozes.

Azevedo, D. (2004). A Igreja Católica e seu Papel político no Brasil. Estudos Avançados , 18.

Barbosa, F. M. (2007). Comunidades Eclesiais de Base na história social da Igreja Caricica (1973-1989). Dissertação apresentada ao programa de pós-graduação em história da Universidade Federal do Espírito Santo vitória. disponível em: http://www.dhnet.org.br/dados/teses/edh/tese_barbosa_cebs_cariacica.pdf.

Bezerra, A., Garcia, P. B., Duarte, N., Massadar, C., \& Ribeiro, V. M. (1985). Caderno de Educação Popular no․ Petrópolis: Vozes.

Beozzo, J. O. (1985). O Vaticano II e a Igreja Latino-Americana. (L. J. Gaio, Trans.) São Paulo: Edições Paulinas.

Bloch, M. (2002). Apologia da História ou O Ofício de Historiador. (A. Telles, Trans.) Rio de Janeiro: Jorge Zahar Editor.

Boff, L. (1982). Igreja: Carisma e poder. Ensaios de Eclesiologia Militante (3 ed.). Petropólis: vozes.

- (1990). nova evangelilzação, perspectiva dos oprimidos. Fortaleza: Vozes.

Boff, L., \& Boff, C. (2001). Como fazer Teologia da Libertação. Petrópilos: Vozes.

Bruneau, T. C. (1974). Catolicismo brasileiro em época de transição. (M. Oliva, Trans.) São Paulo: Edições Loyola.

Brasil. (26, março 1961). Decreto no 50.370, de 21 de Março de 1961.

- (1967, março 14). Decreto № 60.464. Brasília .

- (1967, agosto 8). Decreto no 61.145.

Bredariol, C. S. (2019, agosto 25). (P. V. Pinto, Interviewer, \& D. P. Silva, Editor) Rio de Janeiro, RJ.

- (1990). Ecologia, ecodesenvolvimento e educação ambiental . dissertação de mestrado apresentado ao programa de Pós-Graduação em educação da Fundação Getúlio Vargas . Rio de Janeiro: FGV.

Bueno, E. (2012). Brasil: uma história: cinco séculos de um país em contrução . Rio de Janeiro: Leya.

Caliman, C. (2004). Do minstério ao Povo de Deus: ma eclesiologia de comunhão. In P. S. Gonçalves, \& V. I. Bombonatto, Concílio Vaticano II, Análise e prospectivas (pp. 228- 248). São Paulo: Paulinas.

Celam. (1968). Conclusões da II Conferência Geral do Episcopado Latino-Americano. Retrieved 2020, from https://www.faculdadejesuita.edu.br/eventodinamico/eventos/documentos/documentoFwdDtt9v3ukKPDZq.pdf

Certeau, M. d. (1982). A escrita da História. (M. d. Menezes, Trans.) Rio de Janeiro: Forense Universitária.

Chabalgoity, D. (2015). Ontologia do oprimido: construção do pensamento filosofico em Paulo Freire. Jundiaí: paco.

CNBB. (1967). Campanha da Fraternidade 1967. Rio de Janeiro: CNBB.

- (n.d.). CNBB Campanhas. $\quad$ Retrieved $03 \quad 21, \quad 2020$, from https://campanhas.cnbb.org.br/campanha/fraternidade1971

- (1971). Documento-base e subsídiosde organização da Campanha da Fraternidade de 1971. Rio de Janeiro: CNBB.

- (1969). Subsídios liturgicos e síntese do documento-base, Campanha da Fratenidade: Para o outro o próximo é você. Rio de Janeiro: CNBB.

- (1970). Síntese do documento-base e subsídios de planejamento. CF 1970. Rio de Janeiro: CNBB. 
Costa, R. P. (2018). tese de doutorado apresentada ao programa de Pós-Graduação em Educação da PUCRio. Poder e negociação como relações pedagógicas. Memória da pesquisa confronto de sistemas de conhecimento na educação popular . Rio de Janeiro : PUC-Rio.

Monteiro, J. R. (Composer). (2019). entrevista realizada com ex-integrante da equipe nacional do MEB. [P. V. Pinto, Performer] Rio de Janeiro, RJ, Brasil: D. P. Silva.

De Kadt, E. (2007). Católicos radicais no Brasil. (M. V. Rezende, \& M. V. Rezende, Trans.) Brasília: UNESCO, MEC.

Dietrich, A. M., Blanes, J. S., \& Santos, S. L. (2017). Educação, Ética e Regime Militar no Brasil. Santo André SP: Universidade Federal do ABC.

Fávero, 0. (2006). Uma Pedagogia da participação popular: Análise da prática educativa do MEBMovimento de Educação de Base (1961/1966). Campinas - SP: Autores Associados.

- (1983). Cultura Popular e Educação Popular: memória dos anos 60. Rio de Janeiro: Edições Graal.

- (1982). Movimento de Educação de Base memória 1961/71. Rio de Janeiro: Fundação Getúlio Vargas, Instituto de Estudos Avançados em Educação.

Fausto, B. (2015). História do Brasil. São Paulo: EDUSP.

Folha, d. S. (1968, dezembro 9). Almanaque folha. Retrieved março 11, 2020, from http://almanaque.folha.uol.com.br/brasil_09dez1968.htm

Frei Guimarães, A. R. (1978). Comunidades de Base no Brasil: uma nova maneira de ser em Igreja. Petrópolis: Vozes.

Freitas, M. C., \& Biccas, M. d. (2009). História social da educação no Brasil (1926-1996). São Paulo: Cortez.

Geraldo, L. (n.d.). Nação do Divino. Retrieved julho 09, 2020, from http://2.bp.blogspot.com/9uULmHmajpU/UwzByVU_20I/AAAAAAAAAFM/oB7Y030ZV4s/s1600/Lamento+do+povo.png

Gotay, S. S. (1981). Teologia Contemporânea: Origem e desenvolvimento do pensamento cristão revolucionário a partir da radicalização da doutrina social nas décadas de 1960 e 1970. In J. 0. Beozzo, O. Maduro, R. Azzi, G. Gutierrez, E. Hoornaert, A. C. Peláez, et al., História da Teologia na América Latina (pp. 139-164). São Paulo: Edições Paulinas.

Jornal do Brasil. (1967, abril 30). Rio de Janeiro: Jornal do Brasil.

José. (n.d.). Medianeira. $\quad$ Retrieved março 18, 2020, from http://medianeirabr.blogspot.com/2013/01/campanha-da-fraternidade-cf.html

Löwy, M. (1991). Marxismo e Teologia da Libertação. (M. V. Baptista, Trans.) São Paulo: Cortez.

Mainwaring, S. (1989). Igreja Católica e política no Brasil 1916 - 1985. (H. B. Prieto, Trans.) São Paulo: Brasiliense.

MEB. (1970b). Metodologia da Ação educativa do MEB.

- (1972b). O trabalho do Movimento de Educação de Base no desenvolvimento social. Rio de janeiro.

- (1969). Relatório anual de 1968. Rio de Janeiro.

- (1968). Relatório anual de 1967. Rio de Janeiro, Brasil.

- (1970). Relatório anual de 1969. Rio de Janeiro.

- (1971). Relatório anual de 1970. Rio de Janeiro.

- (1972). Relatório anual de 1971. Rio de Janeiro.

- (1967, outubro 11 - 31). Relatório do V Encontro de Coordenadores. Rio de Janeiro.

- (1969b). Relatório para Assembléia Geral da CNBB. Rio de Janeiro.

- (1698). Relatório Síntese para audiência com o Presidente da República, 20 de maio de 1968. Fundo MEB no CEDIC - digitalizado por Paulo Vitor de Souza Pinto.

Mitidiero, M. A. (2008). Tese de Doutorado. A ação territorial de uma igreja radical: Teologia da Libertação, Luta pela Terra e Atuação da Comissão Pastoral da Terra no Estado da Paraíba. São Paulo.

Paiva, V. P. (1983). Educação popular e educação de adultos. São Paulo: Loyola.

Pape, C., Comblin, J., Gorsky, J., Maiello, G., Galilea, S., \& Marins, J. (1983). A misão a partir da América Latina. (E. Flavian, Trans.) São Paulo: Paulinas.

Paulo VI, P. (1967). Documentos de Paulo VI: Populorum Progressio. (L. Costa, Trans.) São Paulo: Paulus. 
Paulo VI, P. (1971, fevereiro 27). Radiomensagem do Papa Paulo VI aos Brasileiros por Ocasião do Início da Campanha da Fraternidade 1971. Retrieved março 2020, from Vaticano: https://m.vatican.va/content/paul-vi/pt/letters/1971/documents/hf_pvi_let_19710227_fraternita-brasile.html

Pontual, P. (2009). Educação Popular e Democratização das estruturas políticas e espaços públicos. In P. Pontual, \& T. ireland, Educação Popular na América Latina: diálogos e perspectivas (pp. 91-101). Brasília: Ministério da Educação: UNESCO.

Oliveros, R. (1990). História de la Teología de la liberación. In I. E. SOBRINO, Mysterium liberationis. Conceptos fundamentales de la Teología de la Liberación (pp. 17-50). Editorial Trota.

Reis, D. A. (2014). A vida política. In D. A. Reis, Modernização, ditadura e democracia: 1964-2010 (1 ed., pp. 75-180). Rio de Janeiro, Brasil: Objetiva.

Ridenti, M. (2014). Cultura. In D. A. (org.), \& L. M. Schwarcz (Ed.), Modernização, ditadura e democracia 1964-2010 (1 ed., Vol. V, pp. 233-284). Rio de Janeiro: Objetiva.

Rolim, L. C. (1969). Le Mouvement d'Education de Base ou Brésil. dissertação apresentada ao programa de Pós-Graduação em educação e desenvolvimento do Institut international de recherche et de formation Education et développement. Paris: I.R.F.E.D.

Saviani, D. (2011). História das ideias pedagógicas no Brasil (3 ed.). Campinas - SP: Autores associados.

Vanzella, J. A. (2017, 10 02). Campanha da fraternidade: A Igreja do Brasil a serviço da vida. Retrieved 03 20, 2020, from Tese apresentada ao Programa de Pós-Graduação em Teologia da PUC - RJ: https://www.maxwell.vrac.puc-rio.br/colecao.php?strSecao=resultado\&nrSeq=31618@1

Vóvio, C. L. (n.d.). Glossário Caele. (L. e. Centro de Alfabetização, Producer, \& Universidade Federal de São Paulo-UNIFESP / Departamento de Educação, Curso de Pedagogia e Programa de Pós-Graduação em Educação e Saúde na Infância e na Adolescência,) Retrieved junho 16, 2020, from http://www.ceale.fae.ufmg.br/app/webroot/glossarioceale/verbetes/alfabetizacao-funcional

Wanderley, L. E. (1984). Educar para transformar: Educação popular, Igreja Católica e política no Movimento de Educação de Base. Petrópolis: Vozes. 